\title{
The Politics of India's Economic Liberalisation Agenda
}

\author{
Ramesh Thakur
}

I

N 1995, India began to be ranked as joint top investment prospect with South Korea among the ten big emerging markets. This partly reflected scepticism about the legal integrity of Cluna's contract laws concerning foreign investors. Yet in August 1995, the government of Maharashtra, India's most industrialised state, cancelled the contract for Houston-based Enron's Dabhol Power Co. project, the biggest single foreign investment to date in the country. Ironically, Prime Minister P. V. Narasimha Rao was in Malaysia at the time, trying to encourage further investment from Southeast Asia. Rao, who has been responsible for the most radical departure from four decades of socialism, tried to downplay the significance of the Euron reversal. Nevertheless, it was clear that the issues were being clarified for the general election scheduled to be held within a year of the decision. Political expediency seemed once again to be in conflict with economic rationality.

\section{Strategic Choices in 1947}

The strategic choices that Indian policy-makers made after independence was achieved in 1947 reflected historical and political as well as economic considerations. The Nehru Government's strategy was to industrialise India by means of central planning. The achievements were substantial. Breaking with pre-independence stagnation, India's economy grew thrice as fast in the 1950s and 1960s as during the Raj. In marked contrast to recurrent famines under the Raj, food security was achieved. In just 40 years, infant mortality was halved, life expectancy nearly doubled, and adult literacy almost trebled (see Table 1). Even so, the chosen path of development retarded further growth.

Bhagwati (1993) argues that India's persistent low productivity is explained by extensive bureaucratic controls over production, investment and trade; inward-looking trade and investment policies; and an inefficient, over-extended public sector. Together, these created a rentier instead of an entrepreneurial economy. Industrial capacity was under-utilised, allocations of foreign exchange and investment capital were inefficient, land reforms were blocked. A generally corrupt polity, based on a stable exchange relationship between bureaucrats, politicians and a narrow circle of propertied and favoured groups, severely inhibited development. 


\section{Table 1}

\section{India's quality of life indicators, 1901-93}

\begin{tabular}{|lcccccccc|}
\cline { 2 - 7 } \multicolumn{1}{c|}{} & 1901 & 1921 & 1941 & 1951 & 1978 & [ & 1998 \\
\hline Infant mortality (per 1000 live births) & & & & 183 & 132 & 80 \\
\hline Life expectancy (years) & 20 & 21 & 31 & 32 & 51 & 61 \\
\hline Adult literacy (per cent) & 6 & 8 & 15 & 17 & 29 & $48^{*}$ \\
\hline
\end{tabular}

*1990.

Sources: Tomlinson (1993:4); World Bank, World Development Report, annual volumes.

The Indian mixed economy suffered from internal contradictions. The goal of massive and rapid industrialisation required a shift in resources from the agricultural to the industrial sector. But as 70 per cent of the people lived in the countryside and were dependent on the farming sector, attempts to help the poor meant directing increasing resources to the rural economy. It also required state support for small, labour-intensive farms at the expense of bigger capital-intensive industries. Small units attracted government support. The goal was to boost employment, since small-scale industries employed more workers per unit of output and capital. 'The effect was to proscribe the expansion of successful small firms, discourage economies of scale and encourage high-cost production. The result was that India ended up with inefficient small companies and monopolistic large ones.

Externally, India had one of the most protected economies in Asia, in stark contrast with the East Asian dragons. By erecting frontier protection and fortifying it with an array of policy instruments such as import-substitution policies, the government forced the people to pay more for consumer goods and the producers to allocate resources on the basis of false prices.

A complicated mix of mutually undercutting policies eventually created an impossibly labyrinthine command economy. The prices of inputs were raised by inefficient state enterprises and by regulating and protecting the private sector. More than 40 years of industrial licensing created delays in investment, cost escalations, slow growth in output and employment and perennial market shortages. Designed to guard the public interest against private monopolists, the Monopolies and Trade Practices Act protected the public sector monopolies against the public interest.

Since the 1970s, India has had a reputation for for economic stagnation, structural rigidity and backwardness, emergency infusion of international capital to stave off defaults, and persistent poverty and inequality. While South Korea and Singapore have left the poorer countries further and further behind, India has slipped behind even the low-income economies' average (see Table 2). World Bank data show that India's 1993 infant mortality rate of 80 deatls per 1,000 live births was much higher than that

\footnotetext{
It is worth noting that much of India's labour legislation is a legacy of the British Raj, which protected British manufactures by, among other means, raising labour costs in India.
} 
of East Asian countries: China 30, Hong Kong 7, Malaysia 13, Singapore 6, South Korea 11, Thailand 36 (World Bank, 1995b:214-15). If East Asia provides examples of successful if selected intervention, then 'South Asia has traditionally been the region where government interventions have done the most economic harm in the past' (Lal, 1993:117).

\section{Table 2}

India's continuing relative poverty, 1976-92

\begin{tabular}{|lrrccc|}
\hline & CNP/capita (USS) & Rank by GNP/capita \\
\hline & 1976 & 1993 & $1976(N=125)$ & $1993(N=132)$ \\
\hline Low income economies & 150 & 380 & - & - \\
\hline India & 150 & 300 & 108 & 113 \\
\hline Singapore & 2,700 & 19,850 & 36 & 14 \\
\hline South Korea & 670 & 7,660 & 64 & 28 \\
\hline
\end{tabular}

Source: World Bank, World Development Report, annual volumes.

\section{Market Reforms in 1991}

The accumulating economic stagnation produced a major balance-of-payments crisis in 1991 as India's foreign exchange reserves fell to US\$1 billion, enough to cover just two weeks' imports. The crisis forced Delhi to look abroad for emergency capital infusion. Yet the world outside lad changed fundamentally since 1947 . The minority Rao government assumed power in India at a time of an emerging new global consensus on economic development policy: a non-inflationary macroeconomic policy built around modest budget deficits and prudent monetary policy, greater openness to trade and foreign investment and greater reliance on market forces as efficient allocators of resources. The government began to tackle the underlying structural deficiencies by dismantling the apparatus of controls and the culture of subsidies and lossmaking public sector enterprises, and opening up the country to foreign investment. The national economic crisis and the fundamental intenational political and economic changes helped the government to break with the decades-old consensus on socialist economic policies. Whereas the centrally plamned USSR had collapsed, China had itself enthusiastically embraced economic liberalisation. A political factor was also at work in India: no group in parliament want to precipitate another election by bringing down the government.

The reforms that have been instituted are mainly macroeconomic, including a gradual removal of quantitative restrictions on imports; a lowering of tariff barriers and of import duties on many items, including inputs for export production; and convertibility for the rupee on the trade account. Industrial sectors that were previously 
reserved for the public sector, such as hydrocarbons, power, roads and ports, have been opened up to domestic and foreign investors.

The realisation that a new economic policy was necessary coincided with the collapse of 40 years of strategic certainties in India's foreign policy. The combination of a centrally planned economy in the USSR and a mixed economy in India generated both Indo-Soviet economic cooperation and irritation (Thakur \& Thayer, 1992: ch.7). In the 1990s, the imperatives of India's domestic economy demanded a reorientation of foreign policy towards Europe, Japan and the United States. But improved relations with these countries would be difficult so long as India's economy was not liberalised both domestically and extemally. Only the West and the major USdominated multilateral institutions (the IMF and the World Bank) can provide India with the necessary amounts of aid, credits and investment. India needs US money, business, market and technology, as well as the help of expatriate Indians living in the US, to maintain its economic momentum. The US is India's most important trading partner and also India's largest foreign investor, accounting for 42 per cent of the US $\$ 2$ billion approved by India in 1993 - roughly equal to the cumulative total investment in the 40 years up to 1991 .

\section{The Dragon and the Elephant}

The prospects of China and India, the largest Asian countries, can be fruitfully compared. Both can exploit matching 'comparative advantages': huge, hard-working populations that achieve high rates of saving because, though poor, they are thrifty. Both at home and abroad they have been successful entrepreneurs.

China enjoys some big advantages. India still suffers from a reflexive antipathy towards multinational corporations. But foreign investment would improve Indian industry's access to higher technology and modern managerial and marketing skills; stimulate domestic competition which has been constricted by import, entry and exit barriers; improve domestic quality control standards; create more employment; and enhance competitiveness. In Southeast Asia, foreign investment has been a key to economic success. Continuing economic failure leaves India vulnerable to outside criticism and pressure; economic success will transform it from a dependent into a self-reliant nation.

India's liberalisation failed to generate immediate enthusiasm from foreign investors. Several factors have been blamed, such as social volatility after the destruction of the Ayodhya mosque in 1992, financial dislocation after the 1993 Bombay bomb blasts and fear of potential political and social instability. A better explanation is that the benefits of foreign investment can be maximised only in a market that is freer than India's yet is. India has the attraction of a sizeable market and a plentiful and cheap labour force. But foreign investors also look for productive labour; managerial, technical and operational skills; access to world-price inputs free of tariff distortions and bureaucratic controls; an expanding domestic base of suppliers and services; and reliable and efficient infrastructure.

India needs to devote more resources to human capital formation (education, skills and training) as well as to power, transport and communications infrastructure. 
The administrative culture needs to be transformed from a suspicious to a helpful attitude towards foreign investment. Flexible labour markets are a crucial component of competitiveness in a dynamic economy; but India's inflexible labour laws make shedding of excess labour difficult and costly. In all these respects, China outscores India and so attracts considerably higher volumes of investment. China's authoritarian rulers can forcibly keep wage rises below productivity increases. Though lower than earlier levels, China's investment inflow in 1994 was still almost US $\$ 28$ billion, much more than the the $\$ 4.5$ billion coming into India since liberalisation began four years ago.

China's liberalisation program had a 13-year headstart on India's. China also has the invaluable asset of Hong Kong, and benefits from the large expatriate Chinese community that provides much of its capital and managerial resources. By contrast, the smaller expatriate Indian community is made up mainly of professionals. Unlike China, India has not yet begun to exploit the asset of a substantial diaspora of its people overseas. At 39 per cent of GDP, China's gross domestic savings rate is double India's.

But in some respects India has the advantage over China. India already has the sort of grass-roots capitalism and consumer ethic from which a healthy market economy can grow. Official statistics understate the vibrant private sector. India has a rudimentary financial system, a liuge consumer base, a large professional class, an education system with established links to the English-speaking world, a well-developed system of property rights and commercial law, an independent judiciary and a free press. The legal system is important, for example, in bolstering investor confidence against any sudden and unfair policy reversals in the future. Contract has less sanctity in China than in more familiar systems of law. The outcome of the Enron affair will be crucial for this.

India's democracy is stronger than is generally realised. Once the political will was there, India was able to move to currency convertibility within two years of economic liberalisation, whereas Clina still maintained multiple foreign exchange rates for its non-convertible currency 15 years after liberalisation. Moreover, having survived decades of social, political and religious volatility, India can offer investors better reliability in worst-case risk assessment.

India can play off the established economic powers against one another. It can help the US to keep pace with Japan's dominance in Asia. The Japanese have established a commanding presence in East and Southeast Asia, but not in South Asia. Conversely, Japanese interests and capabilities are so mucl at variance with India's that Delhi has never vied for competitive influence with Tokyo. Japan's presence in South Asia is not constrained by memories of wartime hostilities and atrocities. In the past, India figured little in Tokyo's hierarchy of foreign policy priorities because it was relevant neither to Japan's security interests nor to its international economic strategy. Historical and linguistic ties to the West, economic policies of import-substitution and protectionism, and close relations with the USSR kept India at a distance from Japan. By the 1990s, Japanese investment in Clina exceeded that in India by about 20 times. 
Japan is also India's largest aid donor, supplying 40 per cent of the total. There has been no commensurate increase in Japanese trade and investment, due partly to the social and political instability of South Asia, but mainly to the complex and restrictive foreign capital laws and excessive regulation. Even so, India offers a stable and expanding market. But for now the cautious Japanese are awaiting the outcome of the Enron cancellation.

\section{Resilience}

If India is to emulate China's economic record over the past 15 years, its liberalisation drive must be sustainedin the long run. The economic reform program, now into its fourth year, has been indisputably successful on most objective measures. All four key indicators in Figure 1 were heading in the wrong direction in 1991, but are now trending in the right direction. The proportion of Indians living below the poverty line has dropped from 30 to 20 per cent. The current account deficit is below 1 per cent of GDP, annual inflation under 10 per cent, industrial output grew by 8.4 per cent in 1994-95, exports grew by 27 per cent, and food stocks are at a record $37 \mathrm{~m}$ tonnes (The Economist, 12 August 1995). Whereas exports financed 60 per cent of the imports in the 1980s, they now finance 90 per cent. Foreign exchange reserves have risen to $\$ 21$ billion. GDP grew by a modest 1.2 per cent in 1991-92; it is now growing by up to 5 per cent a year. The budget deficit shrank from 8.3 per cent of GDP in June 1991 to 4.7 per cent two years later.

Yet India's economic reforms are incomplete. The insurance market needs to be opened up to foreign investors, barriers to consumer goods removed, the banking sector strengthened, taxes lowered on capital and intermediate goods and government regulations reduced. Prospective investors are still frustrated by inadequate infrastructure, Delhi's slow pace on regulatory and price settings, and obstacles to actual implementation of investment plans. Other concens relate to still-high import tariffs (India's import-weighted average tariff is 40 per cent), inadequate legal protection of intellectual property, and weak enforcement of existing laws.

What the govennment has done so far is thus better described as 'stabilisation'. It has yet to create genuine competition and free trade (many consumer goods still cannot be imported), tackle labour market reform, and generally establish an arms-length relationship between the govenument and business sectors. India's infrastructure and service industries remain in state control because the politicians are reluctant to barter away such strategic sectors as banking, power and telecommunications, and because a large, unionised and inefficient workforce rightly fears for its survival in a competitive environment.

The focus of India's economic agenda must now shift from stabilisation to structural reform. Three principal areas of microeconomic reform remain: labour market and industrial relations (the govenument wants to create a minimal safety net for workers before introducing any 'exit policy'); the farming sector, including the removal of price-distorting subsidies, providing additional infrastructural investment, and abolishing the state-monopoly marketing boards; and the imposition of the new pro-businessattitude on the lower-level bureaucracy and state governments. 


\section{Figure 1}

\section{India's economic indicators, 1980/81 - 1994/95: $\%$ change on a year earlier}

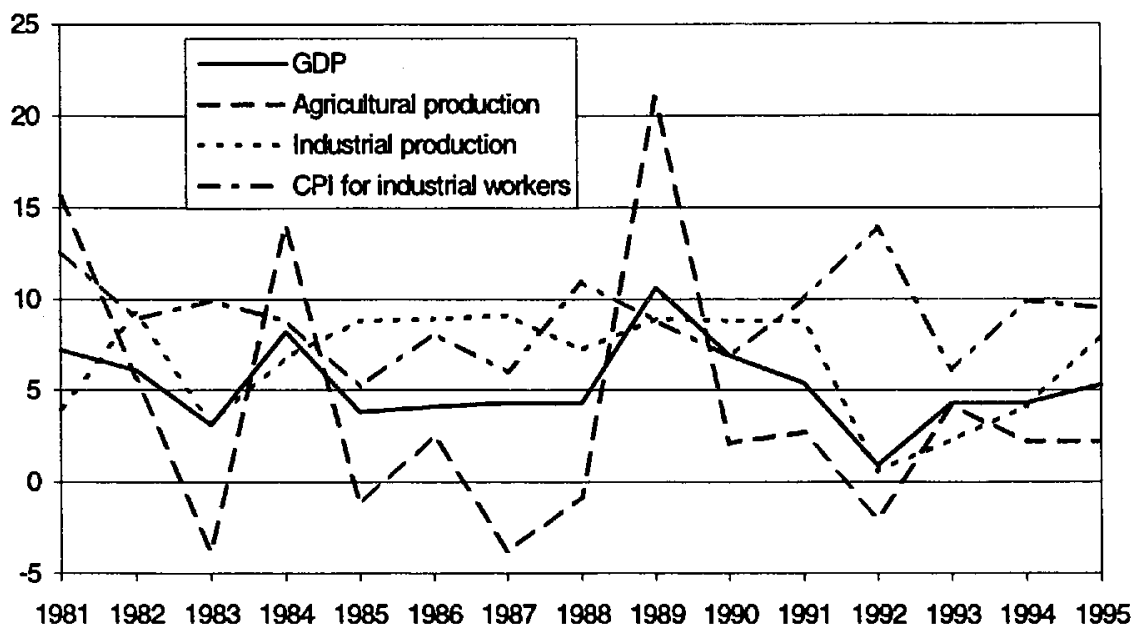

Sources: Government of India (1995); Euromoney Supplement, April 1992.

The federal govenment remains committed to economic reform. But the 1995 budget showed that political imperatives took precedence over economic rationality. Investors were disappointed at the lack of any new impetus to the reform program. Instead, stung by criticism that the reform process has done little to benefit the poor, the government announced policies to alleviate poverty (for example, through old age pensions and matemity care) and court the middle class through lower income taxes and excise duties. Having just lost elections in the two industrially crucial states of Gujarat and Maliarashtra, the Congress Party could not afford to exclude populist measures from the budget. That lesson was underlined by the loss in the politically crucial state of Bihar soon after in March.

While the liberalisers argue that the budget failed to broaden or deepen economic reforms, political scientists respond that the budget undercut the ability of the left to embarrass Rao and exploit discord in the ruling party. Yet in May 1995, a group of disaffected party members split away to form a rival party under the leadership of former cabinet ministers Arjun Singh and N. D. Tiwari. Accusing the Rao government of having betrayed the party's socialist ideals, they seek to resurrect the marriage of political expediency and socialist ideology that had proven so electorally successful for Indira Gandhi.

The importance of the political factor has been underlined by the controversy surrounding the Enron's power project in Maharashtra, which was scrapped (though later both sides agreed to try to renegotiate the deal). Part of the Bharatiya Janata Party (BJP) strategy is to identify Congress as the party of corruption catering to the 
interests of rich foreign firms against those of Indian business, consumers and workers. Before, at the time of and after the cancellation of the Enron deal, the BJP insisted that it was not opposed to foreign investment, but it does reject contracts involving lucrative counter-guarantees from the government where the risks are bome by the public and profits accrue to foreign investors. And it does question the propriety and economic rationalism of contracts awarded without competitive bidding. It favours foreign investment, but not in consumer goods. Nevertheless, the BJP remains committed to attracting foreign investment into Maharashtra, where it governs in partnership with the Shiv Sena, and Gujarat, where it is also in power.

The controversy generated by the Eiron cancellation and the debate on the merits of foreign investment and unilateral cancellations of previously signed contracts are healthy developments. In a strongly worded editorial on 5 August 1995, The Hindu (Madras) criticised the Maharashtra government for having allowed 'negative and purely political considerations' to prevail over 'larger national interests'. The financial consequences of the decision, the paper noted, would be borne by the people of the country. The complexities of India's politics can be shown from another angle. The majority of workers at the Dabhol site were lower caste and outcastes. Suddenly urremployed, they attacked the BJP-Shiv Sena govenument for its 'brahminical conspiracy' in halting work on the project (Diwakar, 1995). Since they comprise the largest single voting bloc in India, there is scope for the Congress Party to gain the advantage over the BJP by exploiting this sentiment.

The Enron-led Dabhol Power Co. project had been cancelled by the newlyelected BJP-Shiv Sena govennment of Malarashtra on 3 August 1995 on three grounds: it was alleged to be too expensive, to have been awarded by the previous Congress administration without competitive bidding, and to have been awarded through bribery. On 8 January 1996, the government announced that the deal had been renegotiated. The tariff was to be reduced from the original Rs. 2.40 to 1.86 (one US dollar - 36 rupees); capital costs would come down by about US\$365m; and a regasification facility would be separated into a new company, saving another $\$ 400 \mathrm{~m}$. But the feeling in India was that in most key respects the deal was essentially unchanged. Enron is still the fuel manager of the plant, and the state-run electricity board is contractually bound to purchase 90 per cent of its power generation.

Congress politicians insisted that the government had been compelled to withdraw accusations of bribery, and to reverse the repudiation of the project's first phase as well as the cancellation of the second plase. The fine print of the revised agreement showed that the gains were largely illusory; the only real 'achievement' was ten months' delay. Economic nationalists within the BJP itself were also dismayed and openly complained about the government having sold out to foreign interests, thereby reinforcing the public perception that the state government had had to retreat rather more than Enron. The state government had been forced to realise that its case was very weak under compulsory international arbitration (such legal relief for investors being one of the major advantages that India offers over China); that electricity supply is already up to 20 per cent below demand and falling further behind; and that the 
Enron delay had placed a major hurdle in the way of other states' urgently needed power projects which could only be financed by the international private sector.

\section{State Governments}

State governments account for 56 per cent of expenditure on social services and $\mathbf{8 5}$ per cent on economic services. Rao pointed out after the state elections of December 1994 that even non-Congress state governments have adopted more pro-marketpolicies. The opposition parties might differ on the pace and details of the reforms, but there is a national consensus on the broad direction of economic policy (Far Easten Economic Review, 2 February 1995).

Interestingly, the Marxist Chief Minister of the state of West Bengal, Jyoti Basu, also emphasised the national consensus on economic reforms with regard to deregulation, delicensing and foreign investment to upgrade technology. At a press conference in Washington during a trip to altract foreign investment (Hindu international edition weekly, 1 July 1995), he said the reforms would therefore hold regardless of which party is in power in New Delli after the next election. The state's campaign was backed by a report commissioned from the international management consultancy firm Price Waterhouse, which identified investment opportunities in agricultural, manufacturing and service industries in the state, whose advantages include low settingup costs and proximity to Southeast Asian markets. And it has been successful: since the start of 1993, West Bengal has been second only to Maharashtra in foreign investment approvals (The Economist, 24 June 1995).

This is a remarkable reversal for a chief minister who has ruled West Bengal at the head of a Marxist government since 1977. Not long ago, the state was infamous for frequent power cuts, pot-holed roads and phones that refused to work. Throughout the 1970s and 1980s, local and multinational companies abandoned a businesshostile environment dominated by a militant and unionised workforce and crumbling infrastructure. The long-term costs of disinvestment were impressed on the state government when the basic ethos of economic policy changed in India in 1991. Now state cabinet ministers openly and often talk in reformist, pro-growth terms. The net result is an industrial renewal that has revived memories of Bengal as the industrial heartland of pre-partition India.

This highlights another positive development: competition between the states to attract outside investment. A number of state governments of all political persuasions have become self-confident and aggressive in promoting their comparative advantages. The new chief minister of the BJP-Shiv Sena coalition government in Maharashtra went on an investment-seeking foreign tour very early in his tenure. Chief Ministers $\mathrm{H}$. D. Deva Gowde of Kamataka and Laloo Prasad Yadav of Bihar head Janata Dal governments. The Janata Dal is the party that expelled IBM and Coca-Cola from India in the 1970s. The two ministers went, at the same time, courting Southeast Asian investors. Both promised one-stop clearance windows and expeditious removal of bureaucratic bottlenecks. So understanding of the benefits of market reforms and foreign investment has spread to the states. Moreover, commanding secure majorities in 
their respective state legislatures, Gowde and Yadav can promise political stability to investors nervous about policy changes by replacement governments.

\section{Conclusion}

The combination of democratic populism and bureaucratic elitism gave the worst of both worlds to India and anchored it firmly to a Third World status. To lift itself into the ranks of the developed world, India needs to establish international investor credibility by unleashing market forces and behaving in a fiscally responsible manner.

The distance that India has still to travel on the road to a free market was highlighted recently by the World Bank(1995a), which urged New Delhi to follow through its four-year old economic reforms by cutting farm subsidies, trimming its budget deficit and eliminating legal, regulatory and administrative red tape that impedes private investment in infrastructure. The govenument was also urged to spend more on social services such as primary education and health care.

Yet India is one of very few countries to have pursued a structural adjustment program with minimal adverse consequences. Moreover, the opposition parties in several states have retained economic policies that are favourable to markets and investment. No single political party is expected to win the next general election that must be held by mid-1996. The BJP and Congress could end up with 150-180 seats each in the 545-strong federal parliament, with the Left Front-Janata Dal coalition not far behind. All parties are talking about the advantages of globalisation and markets, differing only on detail. No party promises to bring back industrial licensing, go back to nationalisation or restore taxes, quantitative restrictions and tariffs to pre-1991 levels. None wants to stop foreign investment completely.

And yet, paradoxically, economic policy will for the first time ever be a national issue in the next election. At a party meeting in Surajkund on 25 July, Rao exhorted his audience to grasp the essentials of the new economic policy and then sell Congress as the pioneer of reforms. Private investment in sectors with substantial investment needs, like power and oil, he pointed out, would free up public resources for investment in housing and other social sectors. The party's distinct electoral identity, therefore, is going to be defined in terms of its leading role in implementing the major economic reforms, and the reforms are going to be sold as being vital for alleviating poverty. But this strategy was assisted by populist spending: on $29 \mathrm{July,} \mathrm{Rao} \mathrm{commanded}$ national television to amounce a US $\$ 1$ billion package of welfare measures for school children and the poor.

The differences in emphasis and direction between the political parties mean that the exact fate of reforms will depend on the outcome of the election. The pace of refonn may slow. One group may favour globalisation, the other privatisation. The public and private sectors are in competition for the provision of goods and services; state governments compete against one another; and state bureaus are more appreciative of problems faced by industries in their states (Chandra, 1995). Competition may impose short-term and firm-specific costs and pain, but it can only be for the better in the long term. 
The dynamism of India's economy since the reforms of 1991 cannot conceal chronic and deep-seated problems. The public sector is still large and subject to bureaucratic and political interference, and infects many parts of the economy. Parties still make populist promises at election time, such as greater subsidies to farmers, which exact opportunity costs in investment in education, health and basic infrastructure.

Equally, however, political volatility and persistent economic nationalism cannot disguise a national consensus on the central planks of the reform process. The Enron cancellation, renegotiation and reinstatement may therefore be a symptom of transition pains rather than a prelude to basic policy reversal through shifting political alignments.

\section{References}

Bhagwati, J. (1993), India in Transition: Freeing the Economy, Oxford University Press, New Delhi.

Chandra, S. (1995), 'Reform is the buzzword now', Finauscial Express (New Delhi), 21 July.

Diwakar (1995), 'Caste ramifications of Euron', Eronomic Times (New Delhi), 13 August.

Government of India (1995), Economic Survey 1994-95, Muistry of Funance, New Delhi.

Lal, S. (1993), 'Foreign Direct Investment in South Asia', Asian Development Review 11(1): 103-19.

Thakur, R. \& C. A. Thayer (1992), Soviet Relations with lndia and Vietnam, Macmillan, London.

Tomlinson, B. (1993), The New Cambridge History of India - The Economy of Moden India, 1860 1.970, Cambridge University Press, Cambridge.

World Bank (1995a), India: Renent Eronomic Developments aud Prospects, Washington DC.

—_(1995b), World Development Report 1995, Oxlord University Press, New York. 